\title{
The Arctic Ocean Girculation as simulated in a very high-resolution global ocean model (OGGAM)
}

\author{
Ye. Aksenov, A.C. Coward \\ James Rennell Division, Southampton Oceanography Centre, Empress Dock, Southampton SO14 3ZH, England
}

\begin{abstract}
To investigate the Arctic Ocean Circulation, results from a high-resolution fully global ocean model have been analyzed. The results come from two runs of the Ocean Circulation and Climate Advanced Modelling project (OCGAM) model, developed and run by the Southampton Oceanography Centre, at $1 / 4^{\circ} \times 1 / 4^{\circ}$ and $1 / 8^{\circ} \times 1 / 8^{\circ}$ resolution. The model is based on the Bryan-Semtner-Cox model and has 36 vertical levels. Enhancements include a free surface, an improved advection scheme and an improved treatment of the surface fresh-water flux. The model is forced with a monthly European Centre for Medium-range Weather Forecasts wind-stress climatology. It reproduces many of the fine-scale features found in the Arctic Ocean. The analysis concentrates on several of the key features, including the highly energetic eddy system in the western part of the Beaufort Sea, East Greenland West and Spitsbergen Currents and the detailed structure of the marginal currents along the Siberian and Canadian coasts. Much of the paper is focused on the water transport through the Bering and Fram Straits and through the Canadian Archipelago. Comparisons of the model net fluxes through the straits against observations are presented. The analyses of the results demonstrate the ability of the fineresolution model to simulate features such as small-scale eddies and jets, which have some agreement with the limited observations available.
\end{abstract}

\section{INTRODUGTION}

The recent shifts in research from the investigation of regional features to climate change and long-term variability in the global atmosphere-ocean-land coupled system have initiated intensive developments in large-scale ocean modelling. The polar oceans are an important part of the global climate system and therefore need to be fully understood before we can have confidence in predictions of rapid climate change. However, because of the small Rossby radius in the Arctic Ocean, ocean models covering the region need to use a grid of much less than $10 \mathrm{~km}$ in order to fully resolve the mesoscale features. The present model has sufficient resolution to permit some mesoscale activity and will start to resolve currents and eddies larger than $30 \mathrm{~km}$, providing new insights into the Arctic circulation. Recent improvements in computer power have made such models practical.

\section{DESCRIPTION OF THE MODEL AND MODEL RUNS}

The Ocean Circulation and Climate Advanced Modelling project (OCCAM) model is a level model based on the Bryan-Semtner-Cox "primitive" equations for the ocean. Potential temperature, salinity, surface height and components of the velocity are the prognostic variables which describe the dynamical and thermodynamical states of the ocean. Several enhancements of the original Bryan-Semtner-Cox model were made in order to improve its performance (Webb and others, unpublished). The "rigid-lid" approximation used in the original model was abandoned and a simple tidal model was used to solve the barotropic equations. The second major development includes the introduction of a new advection scheme, termed the Split-QUICK scheme (Webb and others,
1998). This is based on Leonard's QUICK scheme (Leonard, 1979) but splits the operator into pure diffusive and advective parts. The model uses Pakanowski and Philander mixing for the tracer fields, although at high latitudes the vertical diffusion coefficient reverts to its constant background value of $0.5 \mathrm{~cm}^{2} \mathrm{~s}^{-1}$. To obtain a fully global coverage, and to overcome the convergence of the meridians near the poles, two spherical grids were used. The first is a standard latitudelongitude grid covering the South Atlantic, Pacific and Indian Oceans. The second grid, which is rotated so that its "north" pole lies on the geographical equator, covers the North Atlantic and Arctic Oceans. The two grids are fully coupled along the Atlantic equator, and a channel model is used to provide a connection through the Bering Strait. The channel model balances the pressure difference between the Pacific and Arctic ends of the strait by bottom friction in a channel of uniform width $(60 \mathrm{~km})$, length $(30 \mathrm{~km})$ and depth $(20 \mathrm{~m})$. The pressure difference is determined by the prognostic sea-surface heights at each end of the strait. The horizontal resolution in the Arctic Ocean and Nordic seas is about 27 and $14 \mathrm{~km}$ for $1 / 4^{\circ} \times 1 / 4^{\circ}$ and $1 / 8^{\circ} \times 1 / 8^{\circ}$ resolutions, respectively. The model uses an Arakawa-B grid because of its better performance in representing the propagation of short Rossby waves and fronts. The model has 36 levels in the vertical, varying in thickness from $20 \mathrm{~m}$ near the surface to $250 \mathrm{~m}$ at depth. The $1 / 12^{\circ}$ DBDB5 dataset was used to derive the seabed topography. Finally, it is worth adding that the structure of the model code was changed in order to be run efficiently on array processor computers using message passing (Webb, 2000; Webb and others, unpublished).

Both the $1 / 4^{\circ}$ and $1 / 8^{\circ}$ models were forced with a monthly climatological surface stress (European Centre for Mediumrange Weather Forecasts) calculated from data for the period 


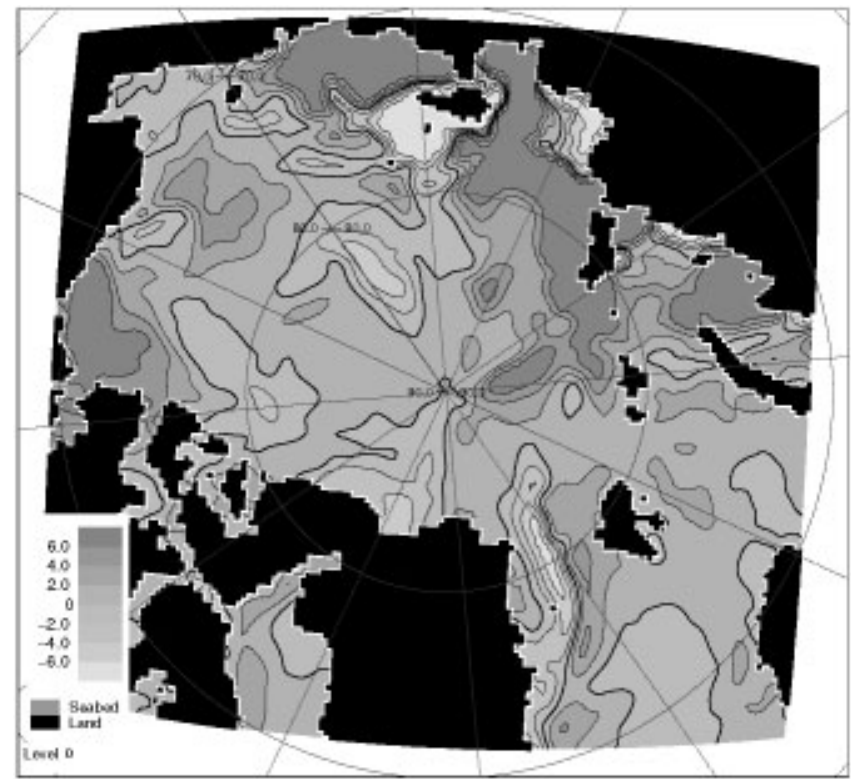

Fig. 1. Annual mean $P-E$ difference $\left(m a^{-1}\right)$ in the Arctic Ocean for the $1 / 4^{\circ}$ model. The 0 isoline is shown in bold.

1986-88. The resulting set of 12 monthly, mean wind-stress fields was applied repeatedly for each model year of integration. The present versions do not include explicit treatments of sea ice, river runoff or atmospheric fluxes of heat and fresh water. Instead both models were "relaxed" to monthly mean climatological temperature and salinity fields (Levitus and others, 1994a, b) with a relaxation time-scale of 30 days. Rather than applying a virtual salt flux, the salinity difference was used to derive a fresh-water flux which could affect the sea-surface height and hence the volume of the surface box. The annual mean $P-E$ difference which results from this process is shown in Figure 1. The values do not exceed $\pm 6.3 \mathrm{~m} \mathrm{a}^{-1}$. High values correlate with areas of river water inflow, and low values with regions of regular ice production (e.g. the Novo Sibirskaya Polynia).

The initial state of the $1 / 4^{\circ}$ model was prescribed by Levitus' climatology (Levitus, 1982). For the first 6 months of integration, temperature and salinity were relaxed to this climatology with a time-scale of 30 days at the surface and 360 days for all other levels. After 6 months the climatology was replaced with Levitus' climatology (Levitus and others, 1994a, b), and the model integrated for a further 3.5 years. After year 4.0, integration continued with surface relaxation only. The model state of year 8.0 of the $1 / 4^{\circ}$ model was used to derive the initial state of the $1 / 8^{\circ}$ model which was integrated forward for two model years using surface relaxation only.

Analysis was carried out on both instantaneous and timeaveraged fields. We used model results from a 4 year period of the $1 / 4^{\circ}$ model (year 8.0-12.0) which comprised full-depth instantaneous fields every 15 days and instantaneous surface fields every 2 days. Results from the second year of the $1 / 8^{\circ}$ model integration, comprising full-depth instantaneous fields every 10 model days, instantaneous surface fields every 5 days and their averages, were employed.

Clearly neither model will have reached an equilibrium state within the analysis period. However, diagnostics, such as the global averaged kinetic energy, temperature change and salinity change, suggest that the circulation patterns are generally established during a 6 month adjustment phase followed by a slow "drift" towards an equilibrium state. We

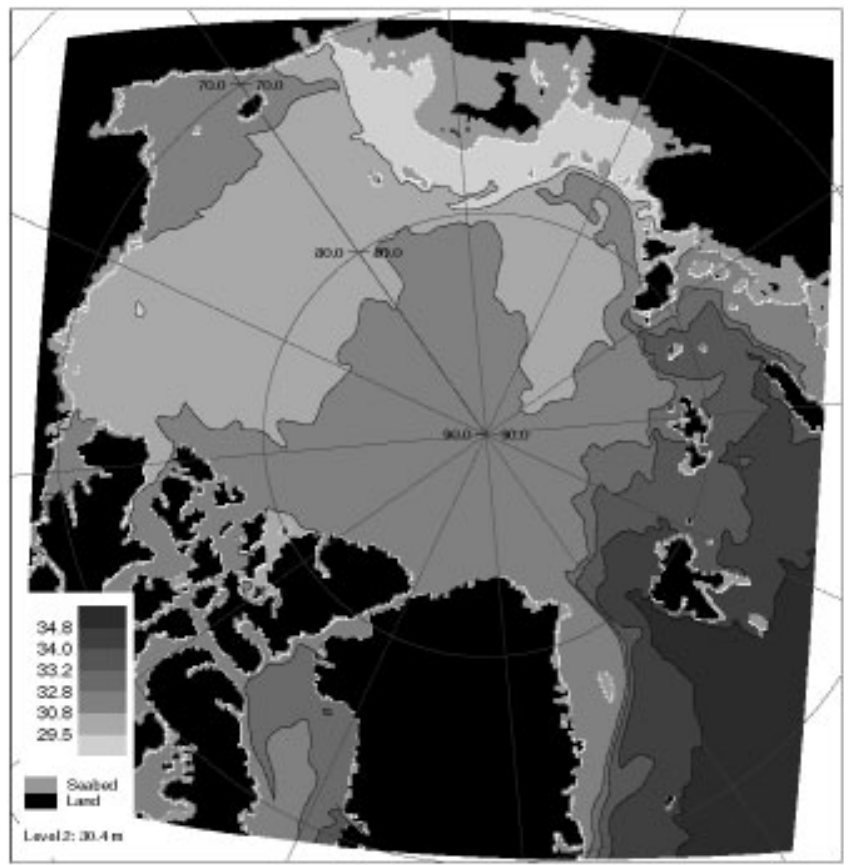

Fig. 2. Annual average of the simulated salinity field ( $p s u$ ) at $30.8 \mathrm{~m}$ depth in the Arctic Ocean. Results from the $1 / 0^{\circ}$ model.

consider that the results from the analysis period give a detailed and coherent view of a possible circulation structure which can be supported by much of the observational data for this area.

\section{LARGE-SGALE OGEAN GIRGULATION AND WATER MASSES}

Because the model is strongly relaxing to Levitus climatological temperature and salinity at the surface, it should not drift very far from the climatology within the integration periods presented. Therefore, comparison between simulated and climatological temperature and salinity fields should confirm that the model has remained close to the present climate. Most new insights are likely to come from analysis of the circulation structure. We have compared simulated hydrographic fields to several sources of observations (e.g. Timofeev, 1961; McLaughlin and others, 1996; NSIDC, 1997). The NSIDC data are derived from Russian archive data not used for Levitus (1994a, b) and show the presence of many fine-scale features similar to the model. A detailed comparison is beyond the scope of this paper, but, generally speaking, good agreement was found between model and hydrographic profiles at selected locations around the Arctic basin.

The model results show a self-consistent picture of the Arctic Ocean Circulation, reproducing the following largescale circulation features observed in the Arctic.

\section{Exchange with the Nordic seas and northern Pacific}

In the model, warm and saline North Atlantic Water flows into the Arctic Ocean through the Barents Sea via St Anna's Trough and through the eastern part of the Fram Strait where it forms the West Spitsbergen Current (WSG) (Fig. 2). The flow gradually descends as it advances further east into the interior of the basin. The water mass has a typical salinity of 34.9-35.2 psu (practical salinity units) and a temperature of 


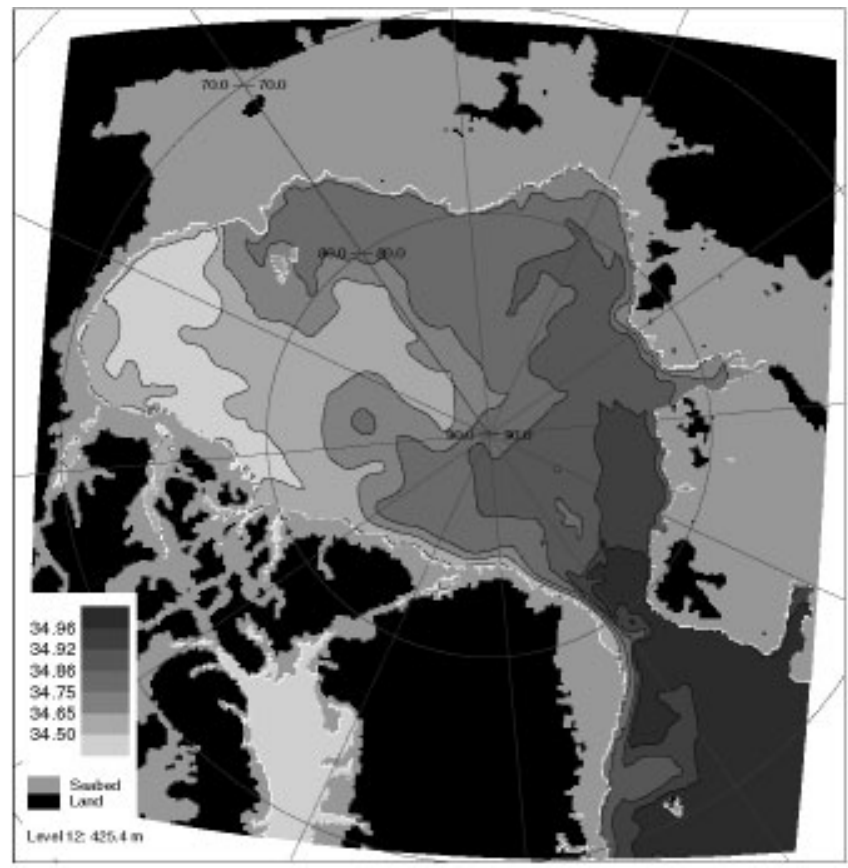

Fig. 3. Annual average of the simulated salinity field (psu) at $425.4 \mathrm{~m}$ depth in the Arctic Ocean. Results from the $1 / 8^{\circ}$ model.

$+0.5^{\circ}$ to $4^{\circ} \mathrm{C}$ (Fig. 2). Strong interactions between the WSC and the southward East Greenland Current (EGC) generate instabilities on the interface (Fig. 3). Eventually, after passing Fram Strait, the stream separates from the shelf slope and forms a meandering eastward current with the core about $100 \mathrm{~km}$ offshore from the shelf slope. The cooled and freshened Atlantic Water finally reaches the eastern boundary of the Makarov basin at 200-800 m depth and also spreads parallel to the slope of the Chuckchi sea shelf in a cyclonic manner (Fig. 3; Fig. 6a, shown later). Taking the $0^{\circ} \mathrm{C}$ isotherm as a rough proxy for the outer limits of the Atlantic water

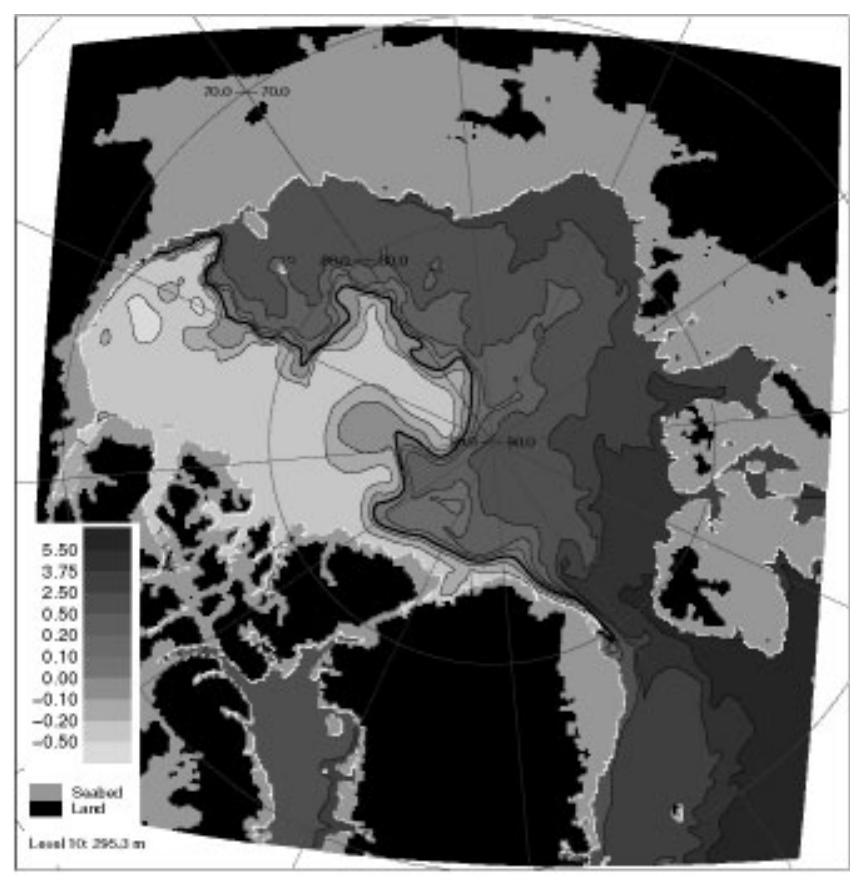

Fig. 4. Annual average of the simulated potential temperature $\left({ }^{\circ} \mathrm{C}\right)$ field at $295.3 \mathrm{~m}$ depth in the Arctic Ocean. Results from the $1 / 8^{\circ}$ model. The $0^{\circ} \mathrm{C}$ isotherm is shown in bold. mass at $300 \mathrm{~m}$, Figure 4 shows how the Atlantic water, in the model, penetrates into the Arctic basin. This is consistent with recent observations, made in the Canadian and Makarov basins (McLaughlin and others, 1996). Relatively fresh North Pacific Water enters the Arctic basin via Bering Strait and has a typical salinity of 30.7-32.4 psu (Fig. 2) and potential temperature of $-1.1^{\circ}$ to $-0.9^{\circ} \mathrm{C}$. A branch of Pacific water flows into the East Siberian Sea as a narrow surface current and forms there a pair of vortices (cyclonic near shore and anticyclonic offshore) (not shown).

\section{Surface circulation}

Here we consider the circulation on the three upper model layers, i.e. at 9.9, 30.4 and $52.3 \mathrm{~m}$ depth. These levels cover the whole depth of the mixed layer in the Arctic Ocean. Currents in the Greenland, Norwegian and Barents Seas, such as Norwegian Coastal Current, WSC, Novaya Zemlia Current and EGC, show a picture consistent with the observations. In addition to the outflow of the Arctic Waters via the EGC, the models reproduce outflow from the Arctic Ocean via the system of currents flowing through the Canadian Archipelago. Avortex system is simulated in the Canadian basin, which produces a net anticyclonic circulation. The Beaufort Gyre can be attributed to this motion. According to the model results, it contains cold and fresh water with a salinity of 28.6-29.4 psu and a potential temperature of about $-1.5^{\circ} \mathrm{C}$. The gyre consists of several pairs of mesoscale vortices and rotates anticyclonically (Figs 5a and 6a). Maximal velocity in the region can reach $30-40 \mathrm{~cm} \mathrm{~s}^{-1}$. The location and strength $\left(5-12 \mathrm{~cm} \mathrm{~s}^{-1}\right)$ of the Trans-Arctic Current is consistent with the observations and results from other models (Proshutinsky and Johnson, 1997; Zhang and others, 1999). However, it does not appear as a single stream in the model, but rather consists of several interconnected small jets. A similar structure emerges from other high-resolution ocean models (see, e.g., Zhang and others, 1999, p. 18,411). Far from the shore, the Arctic Ocean houses many small-scale circulation features, producing a patchy salinity field. Such mesoscale activity was observed indirectly by monitoring ice concentration with the help of imagery from the Special Sensor Microwave/Imager. The Siberian rivers and McKenzie River are the major source of fresh water in the Arctic, and therefore have a great effect on the ocean circulation on the Siberian Shelf. Figure 1 shows how this forcing is applied to the model despite the lack of an explicit treatment of river runoff. In the Laptev and East Siberian Seas, fresh (28.9 psu) (Fig. 2) and cold $\left(-1.1^{\circ}\right.$ to $-0.8^{\circ} \mathrm{C}$ ) water dominates the entire continental shelf. This water is a product of mixing between river waters and West Arctic Surface Water. In the Kara Sea the fresh water is pushed eastward by the intrusion of the saline Atlantic Water. The model results demonstrate the presence of cyclonic circulation in the Barents Sea, the western part of the Kara Sea, the western Chuckchi Sea and the northern part of the Laptev Sea, and anticyclonic circulation in the southern part of the Laptev Sea and the East Siberian Sea. A narrow and energetic surface current with a speed of about $14 \mathrm{~cm} \mathrm{~s}^{-1}$ flows along the continental-shelf slope in the western part of the Laptev Sea and brings saline water (about $31.9 \mathrm{psu}$ ) into the region. The McKenzie River supplies the southern periphery of the Canadian basin with a significant volume of fresh water (salinity about $28.8 \mathrm{psu}$ ) which moves westward along the Alaskan coast. The freshwater source contributes to the density-driven circulation in the vicinity of the Beaufort Gyre. 

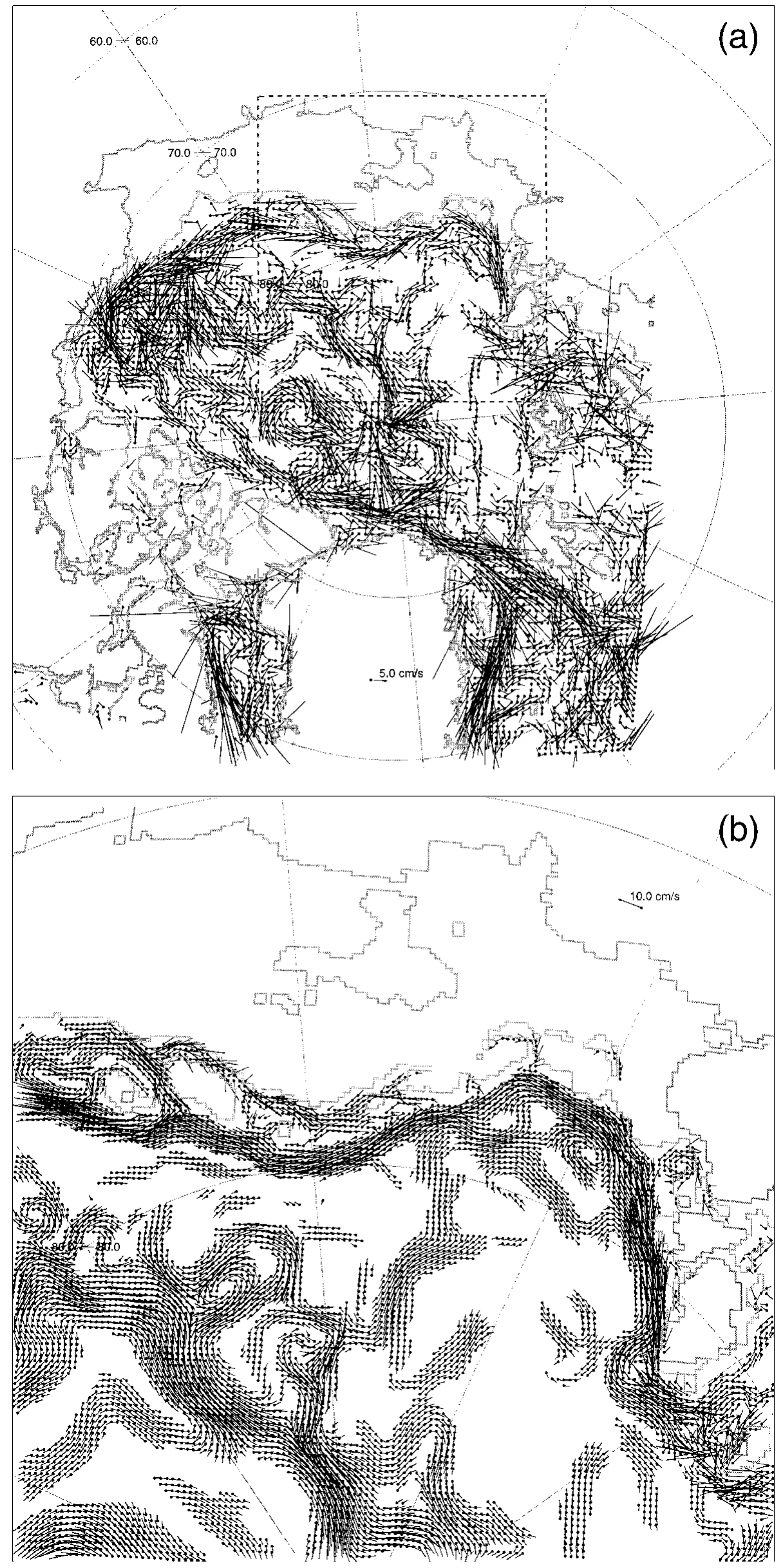

Fig. 5. Annually averaged velocity field from $1 / 8^{\circ}$ OCCAM model at $76 \mathrm{~m}$ for the Arctic basin ( a), and the boundary current along the Siberian Shelf $(b)$. The velocity vectors are drawn every third cell for $(a)$, in order to avoid overcrowding the picture. Vectors of $>100 \mathrm{~cm} \mathrm{~s}^{-1}$ were also truncated for the sake of clarity. Velocities of $<2 \mathrm{~cm} \mathrm{~s}^{-1}$ are not shown. Vectors are drawn as lines with dots at their bases. The area covered by $(b)$ is shown as a dashed rectangle in $(a)$. 

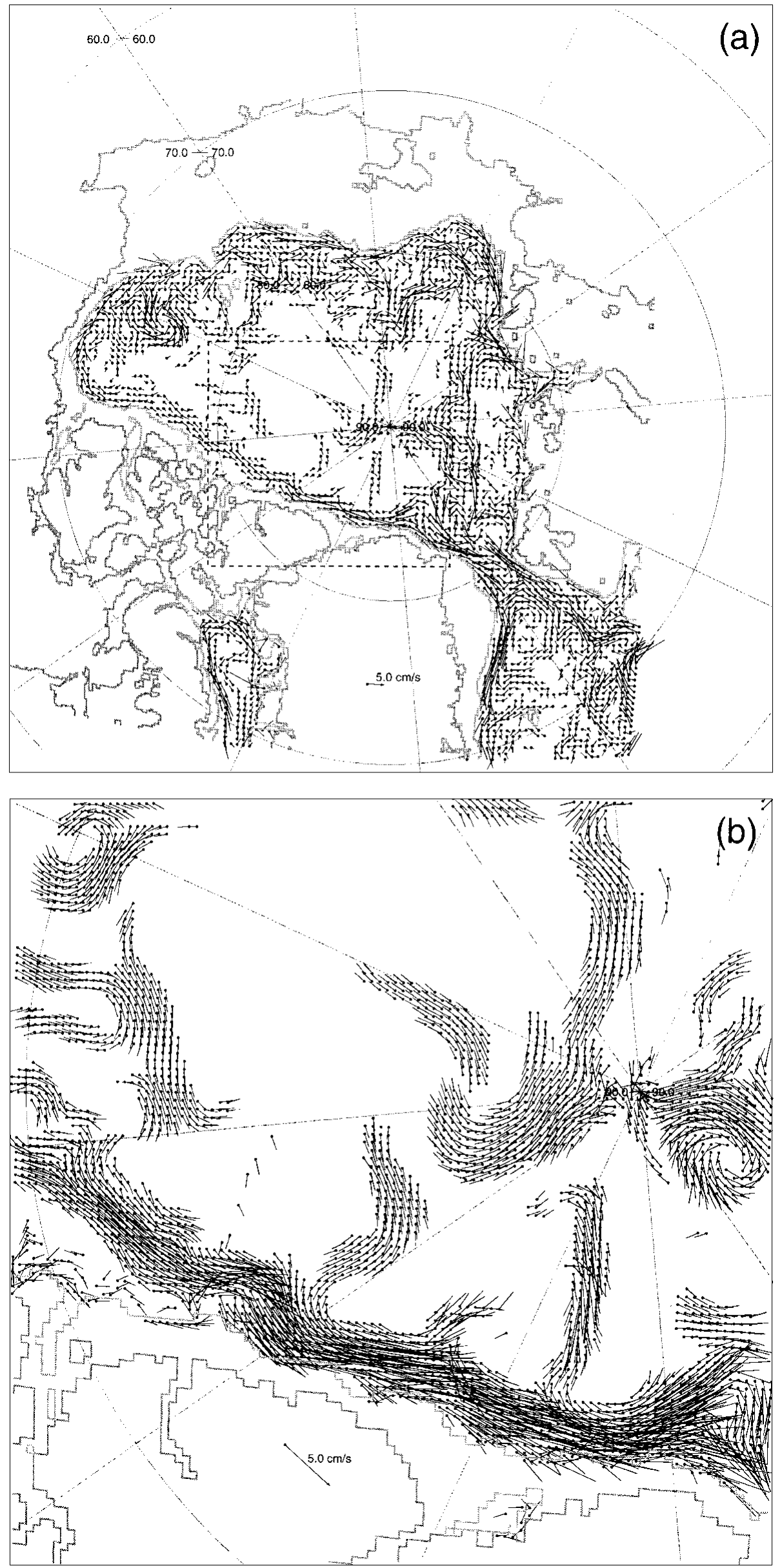

Fig. 6. Annually averaged velocity field from 1/8 $8^{\circ}$ OCCAM model at $425.4 \mathrm{~m}$ depth for the Arctic basin ( a), and the boundary current along the Canadian Shelf $(b)$. The velocity vectors are drawn every third cell for $(a)$, in order to avoid overcrowding the picture. Vectors of $>10 \mathrm{~cm} \mathrm{~s}^{-1}$ were also truncated for the sake of clarity. Velocities of $<1 \mathrm{~cm} \mathrm{~s}^{-1}$ are not shown. Vectors are drawn as lines with dots at their bases. The area covered by $(b)$ is shown as a dashed rectangle in $(a)$. 
Table 1. Simulated and observed water transports (Sv) though the Arctic straits

\begin{tabular}{|c|c|c|c|c|c|c|c|}
\hline \multirow[t]{2}{*}{ Source } & \multirow[t]{2}{*}{ Period } & \multicolumn{6}{|c|}{ Transport } \\
\hline & & Minimal & Month & Maximal & Month & Mean & STD \\
\hline \multicolumn{8}{|c|}{ Bering Strait $\left(65.50^{\circ} \mathrm{N}, 170.62^{\circ} \mathrm{W}: 65.50^{\circ} \mathrm{N}, 167.88^{\circ} \mathrm{W}\right)$} \\
\hline \multicolumn{8}{|l|}{ Simulation } \\
\hline 1/4 OCCAM & Climate & 0.34 & March & 1.12 & June & 0.66 & 0.23 \\
\hline 1/8 ${ }^{\circ}$ OCCAM & Climate & 0.37 & March & 1.26 & June & 0.74 & 0.30 \\
\hline Proshutinsky and Johnson (1997) & $1946-93$ & 0.85 & March & 1.35 & July & 1.10 & - \\
\hline \multicolumn{8}{|l|}{ Observations } \\
\hline Roach and others (1995) & 1990-94 & 0.32 & March & 1.34 & July & 0.84 & 0.30 \\
\hline Coachman and Aagaard (1988) & 1946-82 & 0.54 & Feb. & 1.14 & July & 0.8 & 0.20 \\
\hline Timofeev (1961) & $1941-43$ & 0.50 & March & 1.92 & Aug. & 1.12 & 0.49 \\
\hline \multicolumn{8}{|c|}{ Barents Trough $\left(76.50^{\circ} \mathrm{N}, 16.82^{\circ} \mathrm{E}: 71.20^{\circ} \mathrm{N}, 28.03^{\circ} \mathrm{E}\right)$} \\
\hline \multicolumn{8}{|l|}{ Simulation } \\
\hline $1 / 4^{\circ}$ model & Climate & 1.38 & Aug. & 4.31 & Nov. & 2.72 & 0.74 \\
\hline $1 / 8^{\circ}$ model & Climate & 1.38 & Aug. & 3.84 & Nov. & 2.39 & 0.69 \\
\hline \multicolumn{8}{|l|}{ Observations } \\
\hline Blindheim (1989) & - & 1.0 & July & 3.3 & Dec & 1.9 & - \\
\hline \multicolumn{8}{|c|}{ Fram Strait $\left(78.93^{\circ} \mathrm{N}, 17.39^{\circ} \mathrm{W}: 78.94^{\circ} \mathrm{N}, 11.40^{\circ} \mathrm{E}\right)$} \\
\hline \multicolumn{8}{|c|}{ 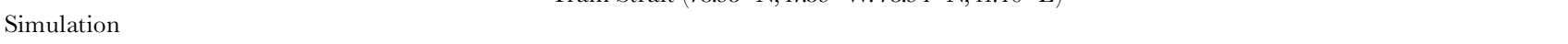 } \\
\hline 1/4 ${ }^{\circ}$ model & Climate & -4.80 & Nov. & -2.40 & Feb. & -3.53 & 0.57 \\
\hline $1 / 8^{\circ}$ model & Climate & -3.79 & Nov. & -1.60 & Feb. & -2.69 & 0.53 \\
\hline \multicolumn{8}{|l|}{ Observations } \\
\hline Fahrbach and others (in press) & 1997-99 & -8.0 & June & 13.30 & Feb. & -0.40 & 2.10 \\
\hline \multicolumn{8}{|c|}{ West Spitsbergen Current $\left(78.87^{\circ} \mathrm{N}, 4.54^{\circ} \mathrm{E}: 78.79^{\circ} \mathrm{N}, 8.63^{\circ} \mathrm{E}\right)$} \\
\hline Simulation & & & & & & & \\
\hline $1 / 8^{\circ}$ model & Climate & 3.13 & May & 6.89 & March & 5.05 & 1.22 \\
\hline \multicolumn{8}{|l|}{ Observations } \\
\hline Woodgate and others (1998) & 1997-98 & 4.0 & June & 16.0 & March & 6.7 & 2.5 \\
\hline Jonnson (1989) & 1971-86 & - & - & - & - & 3.0 & 1.0 \\
\hline Aagaard and Greisman (1975) & $1971-72$ & 5.8 & D-J & 9.4 & $\mathrm{~J}-\mathrm{N}$ & 7.1 & - \\
\hline \multicolumn{8}{|c|}{ Nares Strait $\left(82.16^{\circ} \mathrm{N}, 60.55^{\circ} \mathrm{W}: 82.09^{\circ} \mathrm{N}, 59.37^{\circ} \mathrm{W}\right)$} \\
\hline \multicolumn{8}{|c|}{ (1) } \\
\hline $1 / 8^{\circ}$ model & Climate & -0.63 & NS & -0.38 & NS & -0.50 & 0.07 \\
\hline \multicolumn{8}{|l|}{ Observations } \\
\hline Prinsenberg (1998) & $1982-85$ & -0.67 & May & - & - & - & - \\
\hline \multicolumn{8}{|c|}{ Barrow Strait $/$ Lancaster Sound $\left(74.31^{\circ} \mathrm{N}, 85.49^{\circ} \mathrm{W}: 73.97^{\circ} \mathrm{N}, 86.73^{\circ} \mathrm{W}\right)$} \\
\hline \multicolumn{8}{|c|}{$\log ^{1}$} \\
\hline $1 / 4^{\circ}$ model & Climate & -0.15 & NS & -0.07 & NS & -0.11 & 0.02 \\
\hline $1 / 8^{\circ}$ model & Climate & -0.46 & NS & -0.19 & NS & -0.31 & 0.06 \\
\hline \multicolumn{8}{|l|}{ Observations } \\
\hline Melling (1998) & 1981 & - & Aug. & - & Dec. & -0.45 & 0.25 \\
\hline Prinsenberg (1998) & $1981-82$ & -0.97 & Aug. & -0.24 & Jan. & -0.50 & - \\
\hline & Total flux through the Canadian st & its $\left(1 / 4^{\circ} \mathrm{m}\right.$ & as only Ba & Strait ope & & & \\
\hline Simulation & & & & & & & \\
\hline $1 / 8^{\circ}$ model & Climate & -1.07 & NS & -0.59 & NS & -0.82 & 0.12 \\
\hline Observations & & & & & & & \\
\hline Melling (1998) & - & - & - & - & - & -1.41 & 0.25 \\
\hline & Ellesmere Shelf (84. & $\mathrm{N}, 71.75^{\circ}$ & $7^{\circ} \mathrm{N}, 72.06$ & & & & \\
\hline Simulation & & & & & & & \\
\hline $1 / 4^{\circ}$ model & Climate & -0.32 & NS & 0.18 & NS & -0.02 & 0.11 \\
\hline $1 / 8^{\circ}$ model & Climate & -1.79 & NS & 0.06 & NS & -0.82 & 0.44 \\
\hline
\end{tabular}

Notes: Positive flux corresponds to the flow into the Arctic Ocean, or to the westward flow; D-J, averaged values for the period December-June; J-N, averaged values for the period July-November; NS, no seasonal trend.

\section{Marginal currents}

Cyclonic currents along the boundaries of the major basins are thought to be a permanent feature of the ocean circulation in the Arctic (Rudels and others, 1994; McLaughlin and others, 1996). Observations suggest that the core of the stream is quite narrow and located on the break of the continental shelf (usually at about 300-600 m depth). The direction of the flow is eastward along the $500 \mathrm{~m}$ isobath. This type of flow was observed at several locations along the continental shelf. The current-meter measurements of the marginal current were carried out on the continental-shelf slope north of the Barents Sea, in the vicinity of Lomonosov Ridge in the northern Laptev Sea; near the Alaskan coast; and on the slope of the Canadian Shelf in the Lincoln Sea. These measurements are described in Aagaard (1989), Newton and Sotirin (1997) and Woodgate and others (2001).

The $1 / 8^{\circ}$ OCCAM model also shows the presence of the narrow boundary current flowing along the shelf break around the whole Arctic basin (Figs 5 and 6). This encircling current consists of several main streams and can be tracked upstream to the Barents Sea. From the model results one can 


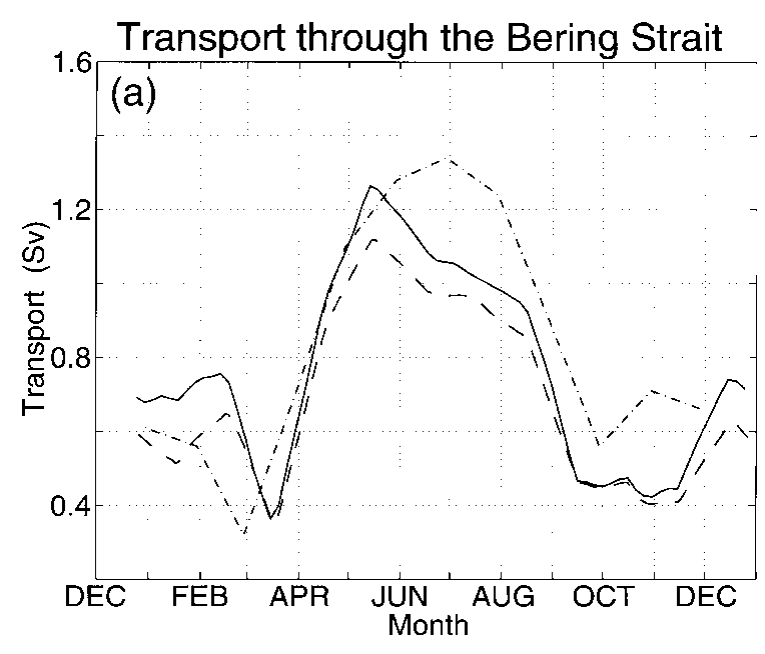

Transport through the Fram Strait

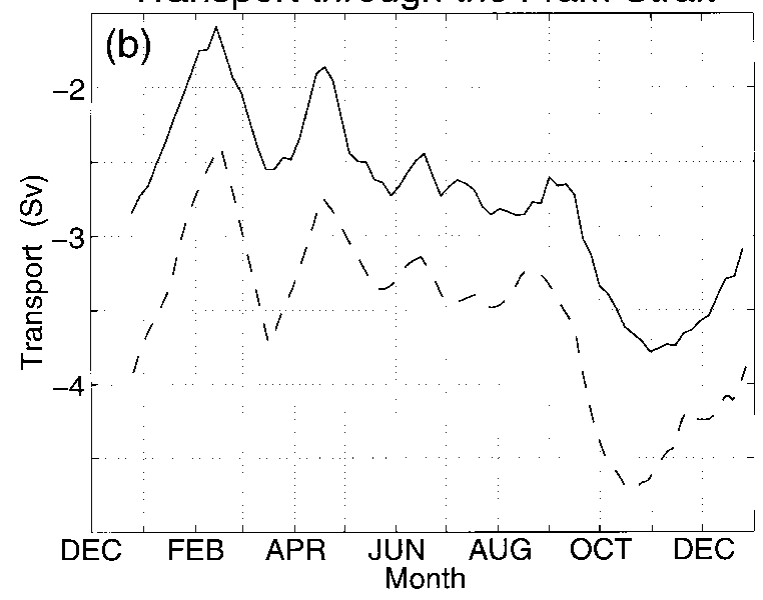

Transport through the Barents Trough
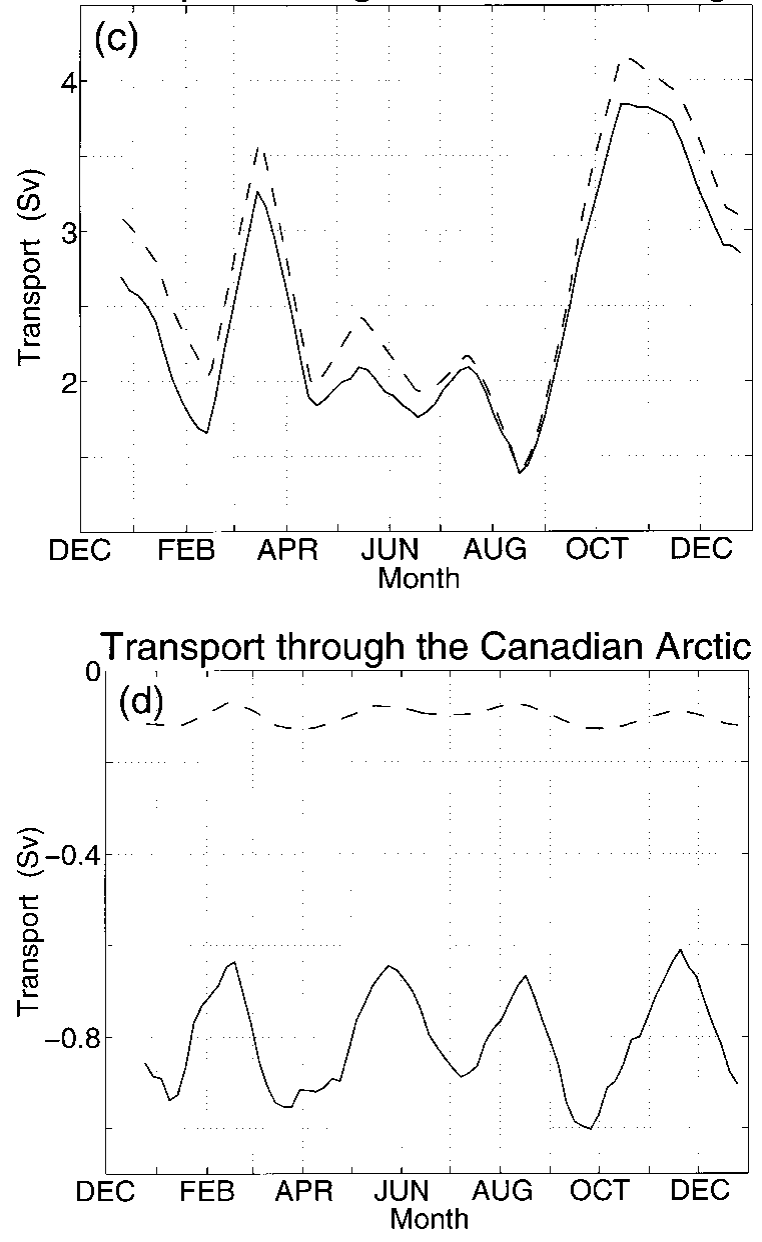

see that the current extends from the surface to around $900 \mathrm{~m}$ along the Siberian, Alaskan and north Greenland coasts. Along the Canadian coast the surface signature is lost and the current is broader and weaker, lying at 130-1100 m depth. According to the simulations, mean velocity in the core along the Siberian, Alaskan and north Greenland coasts is $7 \mathrm{~cm} \mathrm{~s}^{-1}$. Along the Canadian coast the average speed is $4 \mathrm{cms}^{-1}$. Typical mean observed velocities in the core of boundary current are between 5 (Lincoln Sea; Newton and Sotirin, 1997) and $15 \mathrm{~cm} \mathrm{~s}^{-1}$ (Barents Sea northern shelf; Aagaard, 1989), with a variability of about $3-5 \mathrm{~cm} \mathrm{~s}^{-1}$. Observations made near the Alaskan Shelf revealed a mean velocity of about $8 \mathrm{~cm} \mathrm{~s}^{-1}$ (Aagaard, 1989). Recent year-long current-meter measurements made on the Eurasian side of Lomonosov Ridge suggest the presence of a current along the shelf slope with a mean velocity of $2-5 \mathrm{~cm} \mathrm{~s}^{-1}$ (Woodgate and others, 2001). Hence, the simulated and observed velocities are in reasonable agreement and the circulation structure obtained from the model can be taken as a working hypothesis.

\section{Ocean interior}

The model currents in the deep ocean are slow, with a speed of $\leq 1 \mathrm{~cm} \mathrm{~s}^{-1}$. They pretty much follow the topography, and produce complete gyres in each of the basins: Nansen, Amundsen, Makarov and Canadian. The signature of the cyclonic marginal current appears in the velocity field up to $1100 \mathrm{~m}$ depth. In the Canadian basin, plumes descending from the Alaskan Shelf and water sinking in the Beaufort Gyre region transport the water with salinity around $34.91 \mathrm{psu}$ and potential temperatures around $-0.15^{\circ} \mathrm{C}$ into the deep ocean. Simulations show that at depths below $600-800 \mathrm{~m}$ the variation of the salinity is small. Average salinity and potential temperature of the water deeper then $2000 \mathrm{~m}$ in the Eurasian basin are $34.94 \mathrm{psu}$ and $-0.6^{\circ} \mathrm{C}$, respectively, whereas the values for the Canadian basin are $34.95 \mathrm{psu}$ and $-0.5^{\circ} \mathrm{C}$. The direction of the circulation below $1500 \mathrm{~m}$ depth in the western Canadian basin is anticyclonic. According to the simulations, the number of small-scale eddies and narrow jets decreases quickly with depth, but some of these structures can be found even at great depth. Some features penetrate the entire water column, the largest being the Beaufort Gyre itself. Also we found another anticyclonic feature, similar in vertical extent but smaller in horizontal dimensions, in the Eurasian part of the Makarov basin, about $400 \mathrm{~km}$ offshore from the shelf slope. We do not have sufficient evidence from the observations to prove or disprove its existence.

\section{FLOW THROUGH THE ARGTIC STRAITS}

As the first level of validation we consider water transport through the major straits which connect the Arctic Ocean to the World Ocean, and compare these model estimates to the known fluxes. The following five main channels were selected:

Fig. 7. Simulated water transport through the Bering Strait (a), Fram Strait (b), Barents Trough (c) and Canadian straits $(d)$. The results from the $1 / 4^{\circ}$ model (dashed lines) and $1 / 8^{\circ}$ model (solid lines) and observations for the Bering Strait (dash-dotted lines) are shown. Northward and eastward fluxes are positive. 
Transport within the WSC

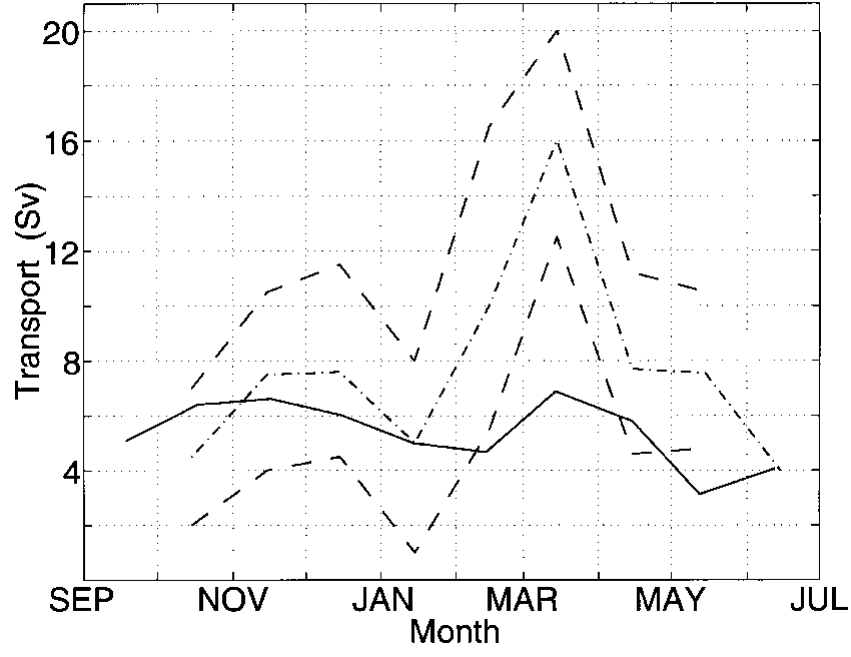

Fig. 8. Water transport within the WSC. The simulated monthly mean transport from the $1 / 8^{\circ}$ model (solid lines) and observations (dash-dotted lines) from Woodgate and others (1998) together with their error limits (dashed lines) are shown. Northward and eastward fluxes are positive.

Bering and Fram Straits, Barents Trough, Nares Strait (which separates Greenland and Ellesmere Island) and Lancaster Sound (eastern part of the Barrow Strait). Narrower straits are not resolved by either version of the model. In addition, the flux through the meridional section located immediately north of Ellesmere Island was calculated in order to check the strength and variability of the boundary current near the Greenland Shelf. For the $1 / 4^{\circ}$ model the Nares Strait is closed, so the water from the Arctic Ocean can enter the North Atlantic only via the Barrow Strait. As will be shown later, this significantly affects the magnitude of the water transport through the Canadian Arctic.

The water transport through the Bering Strait is one of the best defined from observations. These show that the net transport in the strait is always directed towards the north and leads to the permanent inflow of the Pacific Water into the Chukchi Sea. The mean annual flux is about $0.8-1.2 \mathrm{~Sv}$ with variance of $0.2-0.5 \mathrm{~Sv}$ (Table 1). The transport has a strong seasonal variability, with a maximum of about $1.3-1.9 \mathrm{~Sv}$ in June-August and minimum of around 0.3-0.6 Sv in February -March (Coachman and Aagaard, 1988; Roach and others, 1995). A secondary maximum of the transport, with a net flux of about $0.8 \mathrm{~Sv}$, was observed in October-December.

The model results exhibit a seasonal variation of the volume flux through the strait similar to the observed one (Fig. 7a). According to the $1 / 8^{\circ}$ model results, the simulated volume flux varies from $0.37 \mathrm{~Sv}$ in March to $1.26 \mathrm{~Sv}$ in June. The $1 / 4^{\circ}$ model gives very similar figures: $0.34 \mathrm{~Sv}$ in March and 1.12Sv in June. Both models display evidence of the existence of a secondary maximum ( 0.65 and $0.76 \mathrm{~Sv}$ for the $1 / 4^{\circ}$ and $1 / 8^{\circ}$ versions, respectively) in December-February (Fig. 7a). As the graph clearly shows, the coincidence of the observed (Roach and others, 1995) and simulated transports in the Bering Strait is remarkable. Other ocean models employed for the same region show similar volume net flux variability (Table 1; or see, e.g., Proshutinsky and Johnson, 1997).

Transport through the Fram Strait has a major impact on the Arctic Ocean circulation. The strait is about $500 \mathrm{~km}$ wide at the narrowest part, with a sill depth of about $2500 \mathrm{~m}$. It is sufficiently large to house a complex circulation structure. Thus the flux in the Fram Strait is not easy to estimate from observations because of the intricate topography and pattern of currents. Two major streams, the northward-flowing WSC and the southward-flowing EGC, pass through the strait. The WSC branches in the northern part of the strait and loops westward to form a southward counter-current which joins the peripheral part of the EGC. Estimates of the monthly mean volume transports by these two main streams are 3-10.8 Sv for the WSC and 3-11.2 Sv for the EGC (Table 1). Despite the large fluxes, the net transport through the strait is thought to be about $1-3 \mathrm{~Sv}$ towards the Atlantic. At present, the question of whether or not the net flux through the strait has significant seasonal variability is still open, but recent long-term current measurements seem to support this hypothesis (Woodgate and others, 1998). It is believed that the presence of several branches of the WSC and its overall instability can substantially obscure the seasonal signal in the water transport.

Comparison between the volume fluxes calculated from the available current-meter observations and from the model shows that the observed fluxes exhibit greater variability than model ones, but the observed mean net flux is actually smaller. The difference could be attributed to the method used for calculating fluxes from this set of current-meter measurements. Most of the measurements were performed in the western or central part of the strait and did not include the shelf part of the EGC. Therefore the mean outflow from the Arctic Ocean may well be underestimated. This can also affect the flux variability, increasing the range of calculated transports. Both $1 / 4^{\circ}$ and $1 / 8^{\circ}$ models give a net volume transport to the south of about 3.5 and $2.7 \mathrm{~Sv}$, respectively, with average fluctuations of about $0.5 \mathrm{~Sv}$ (Table 1). Besides the obvious seasonal variability the quasi- periodical oscillations with a period of about 50 days are present from February to August (Fig. 7b). We calculated the transport time series for the sections crossing the strait at $76.6^{\circ} \mathrm{N}, 79^{\circ} \mathrm{N}, 79.8^{\circ} \mathrm{N}$, and found such oscillations in all of them. One can hypothezise that the fluctuations could be related to short-period variability in the recirculation between the WSG and EGC or to local wind conditions, but the origin of these oscillations is not yet fully understood. A similar type of variability can be found in the observations (Fahrbach, in press).

We performed a comparison of the simulated and observed water transport within the WSC (Table 1). The average flux for the period October-June calculated from the results of the $1 / 8^{\circ}$ model $(5.37 \mathrm{~Sv}$ ) is lower than that recently observed $(6.7 \mathrm{~Sv})$ during the Variability of Exchange in the Nordic Sea (VEINS) experiment (Fig. 8). However, the simulated transport is in reasonable agreement with other estimations (3-7 Sv) made from observations taken during the last 20 years (see Woodgate and others, 1998, for an overview of past observations).

Transport through the Barents Trough is an important part of the water exchange between the Nordic seas and the Arctic. Simulations give values of 2.39 and $2.72 \mathrm{~Sv}$ for the $1 / 8^{\circ}$ and $1 / 4^{\circ}$ models, respectively (Table 1 ). Weak seasonal variability of the flux is presented and is in the opposite phase to the transport through the Fram Strait (Fig. $7 \mathrm{~b}$ and c).

According to recent publications, the water flux through the Canadian Archipelago is the same order of magnitude as the net flux through the Fram Strait (Melling, 1998; Prinsenberg, 1998). The published figures for the mean annual transport from the Arctic Ocean to the Labrador Sea are 0.7-1.7 Sv. 
Most coarse-resolution models cannot resolve the relatively narrow and shallow channels between the islands of the Canadian Arctic. In our $1 / 4^{\circ}$ version the Arctic Water enters the Labrador Sea via Lancaster Sound (eastern part of the Barrow Strait) only. The $1 / 8^{\circ}$ model has the Nares Strait opened in addition, and allows $0.5 \mathrm{~Sv}$ of the Arctic Water to pass through the passage into the Labrador Sea. The total volume flux from the Arctic Ocean into the Labrador Sea according to the $1 / 8^{\circ}$ model is about $0.8 \mathrm{~Sv}$, which is close to the estimation made by Melling (1997). However, the seasonal structure of the transport variability calculated from the available current observations is different from that simulated in the model (Table 1). The simulated transport $\left(1 / 4^{\circ}\right.$ model $)$ through the Lancaster Sound does not show any significant seasonal variability, with the maximum in October and minimum in June, whereas the transport calculated from the current measurements and hydrographic observations has a minimum in December and a maximum in August (Table 1). Leaving aside the model errors, we would like to emphasize that the seasonal curve proposed by Prinsenberg (1998) is based on single-point year-long current measurements. They in their turn were correlated to the across-strait section completed in April 1982. On the other hand, the absence of an explicit treatment of sea ice in the model, together with the unavoidable coarsening of the topography, leads to an underestimation of the currents in the narrow straits. The model flux has short-period variability over a period of about 70-100 days, very similar to that obtained in the Fram Strait. In the 1/8 model the oscillations are easily noticeable in the Lancaster Sound time series, and completely overwhelm the seasonal signal in the Nares Strait. To understand whether these oscillations are caused by the oscillations of the current on the Canadian Shelf, we analyzed the volume transport from both models through a section across the shelf immediately north of Ellesmere Island. None of the periodic component was found, but rather the signal exhibits chaotic fluctuations. Quarter-degree model results show quasi-periodical variations in the transport but with the Nares Strait closed.

As one can see from Figure 7, the model resolution significantly alters the water transport through the Fram Strait and the Canadian Arctic. By opening the Nares Strait in the $1 / 8^{\circ}$ model we increased the export of water from the Arctic into the Labrador Sea by almost a factor of seven, when the mean annual flux through the Fram Strait dropped by 25\% (Table 1). The resolution had little effect on the water influx through the Bering Strait and Barents Trough (Fig. 7a and c).

\section{CONGLUDING REMARKS}

The main weaknesses of the present model versions are obvious: simplified treatment of the sea-ice evolution and too short an integration period. Despite these weaknesses, the model reproduces realistic and coherent simulations of the Arctic currents and water-mass properties. We would argue that the high-resolution ocean general-circulation model presented here is a very powerful tool for studying both large- and small-scale features in the Arctic. It can also help us to investigate the longer-period variability of the ocean circulation incorporating the correct physics of the small-scale processes.

The great advantage of high-resolution models is in resolving fine-scale structures approaching the order of the Rossby scale or less. One class of such features is small-scale eddies, which are involved in the transport of kinetic energy from the boundary of the Arctic basin into its interior. Other examples of fine structure are the narrow ( $\leq 100 \mathrm{~km}$ wide) eastward boundary currents localized on the continentalshelf slope and literally encircling the entire Arctic Ocean. We have discussed these boundary currents in some detail and shown that they are consistent with hypotheses based on limited observations. However, within the model we also find narrow jets not only near the shelf break but also in the interior of the ocean. Unexpectedly the whole basin is "packed" with these features, in contrast to the shallow waters of the Siberian Shelf. Observing these features will present a significant challenge for future hydrographic programs.

Concerning the future, several model improvements are underway. The first is to couple the ocean model to a sea-ice model. The elastic-viscous-plastic model developed by Hunke (Hunke and Dukowicz, 1997) will be used. This model has a well-tested viscous-plastic rheology, and its fully explicit numerical scheme is efficient for parallel architectures. We hope to maintain the computational efficiency obtained with the current model and thus achieve longer integration periods without having to compromise further on model resolution.

\section{ACKNOWLEDGEMENTS}

We would like to thank our colleagues D. Webb and B. de Cuevas for their valuable help with the analysis of the OCGAM data and also for fruitful discussions. This research was carried out as part of the ARCICE project funded by the U.K. Natural Environment Research Council.

\section{REFERENGES}

Aagaard, K. 1989. A synthesis of the Arctic Ocean circulation. Part 1. Physical and chemical oceanography. Rapport et Proces-Verbaux des Réunions ICES 188, $11-22$.

Aagaard, K. and P. Greisman. 1975. Towards new mass and heat budgets for the Arctic Ocean. 7. Geophys. Res., 80 (27), 3821-3827.

Blindheim, J. 1989. Cascading of Barents Sea bottom water into the Norwegian Sea. Rapport et Proces-Verbaux des Réunions ICES 188, 49-58.

Coachman, L. K. and K. Aagaard. 1988. Transports through Bering Strait: annual and interannual variability. F. Geophys. Res., 93(C12), 15,535-15,539.

Fahrbach, E. and 7 others. In press. Direct measurements of heat and mass transport through Fram Strait. Polar Res.

Hunke, E. C. and J. K. Dukowicz. 1997. An elastic-viscous-plastic model for sea ice dynamics. 7. Phys. Oceanogr., 27(9), 1849-1867.

Jonnson, S. 1989. The structure and forcing of the large- and mesoscale circulation in the Nordic Seas with special reference to the Fram Strait. (Ph.D. thesis, University of Bergen.)

Levitus, S. 1982. Climatological atlas of the world ocean. Rockville, MD, U.S. Department of Commerce. National Oceanic and Atmospheric Administration. (NOAA Professional Paper 13.)

Levitus, S., T. P. Boyer and J. Atonov. 1994a. World ocean atlas 1994. Vol. 4. Temperature. Rockville, MD, U.S. Department of Commerce. National Oceanic and Atmospheric Administration. (NOAA Atlas NESDIS 4.)

Levitus, S., R. Burgett and T. P. Boyer. 1994b. World ocean atlas 1994. Vol. 3. Salinity. Washington, DC, U.S. Department of Commerce. National Oceanic and Atmospheric Administration. (NOAA Atlas NESDIS 3.)

McLaughlin, F. A., E. C. Carmack, R. W. Macdonald and J. K. B. Bishop. 1996. Physical and geochemical properties across the Atlantic/Pacific water mass front in the southern Canadian basin. 7. Geophys. Res., $101(\mathrm{Cl}), 1183-1197$.

Melling, H. 1998. Flow from the Arctic Ocean through the channels of the Canadian Arctic Archipelago: present understanding and future research plans. In Aagaard, K., D. Hartmann, V. Kattsov, D. Martinson, R. Stewart and A. Weaver, eds. Proceedings of the ACSYS Conference on Polar Processes and Global Climate, Rosario, Orcas Island, WA, USA, 3-6 November 1997. Vol. 2. Oslo, International ACSYS Project Office, 164-166.

National Snow and Ice Data Center (NSIDC). 1997. Arctic oceanography atlas for the winter period. Boulder, CO, University of Colorado. National Snow 
and Ice Data Center. Environmental Working Group.

Newton, J. L. and B. J. Sotirin. 1997. Boundary undercurrent and water mass changes in the Lincoln Sea. 7. Geophys. Res., 102(C2), 3393-3403.

Prinsenberg, S. J. 1998. Volume, heat and freshwater fluxes through the Canadian Arctic Archipelago. In Aagaard, K., D. Hartmann, V. Kattsov, D. Martinson, R. Stewart and A. Weaver, eds. Present understanding and future reseach plans. Proceedings of the ACSYS Conference on Polar Processes and Global Climate, Rosario, Orcas Island,WA, USA, 3-6 November 1997. Vol. 2. Oslo, International ACSYS Project Office, 200-202.

Proshutinsky, A.Yu. and M. A. Johnson. 1997. Two circulation regimes of the wind-driven Arctic Ocean. 7. Geophys. Res., 102(C6), 12,493-12,514.

Roach, A.T. and 6 others. 1995. Direct measurements of transport and water properties through the Bering Strait. F. Geophys. Res., 100 (C9), 18,443-18,457.

Rudels, B., E. P. Jones, L. G. Anderson and G. Kattner. 1994. On the intermediate depth waters of the Arctic Ocean. In Johannessen, O. M., R. D. Muench and J. E. Overland, eds. The polar oceans and their role in shaping the global environment: the Nansen centennial volume. Washington, DC, American Geophysical Union, 33-46. (Geophysical Monograph 85.)

Timofeev, V.T. 1961. Water masses of the Arctic basin. Seattle, WA, University of Washington. Applied Physics Laboratory. (Translation of Vodnye massy Arkticheskogo basseina, Gidrometeoizdat, Leningrad, 1960, L. K.
Coachman, $e d$.)

Webb, D. J. 2000. Evidence for shallow zonal jets in the South Equatorial Current region of the southwest Pacific. 7. Phys. Oceanogr., 30 (4), 706-720.

Webb, D. J., B. A. de Cuevas and C. S. Richmond. 1998. Improved advection schemes for ocean models. 7. Atmos. Oceanic Technol., 15(10), 1171-1197.

Webb, D. J., B. A. de Cuevas and A. C. Coward. Unpublished. The first main run of the OCCAM global ocean model. Southampton, Southampton Oceanography Centre. (Internal Report.)

Woodgate, R. A., U. Schauer and E. Fahrbach. 1998. Moored current meters in the Fram Strait at $79^{\circ} \mathcal{N}$ : preliminary results with special emphasis on the WSC. Bremerhaven, Alfred Wegener Institute for Polar and Marine Research. Fachbereich Physik. (Berichte. Variability of Exchange in the Nordic Sea (VEINS)).

Woodgate, R. A. and 7 others. 2001. The Arctic Ocean Boundary Current along the Eurasian slope and the adjacent Lomonosov Ridge: water mass properties, transports and transformations from moored instruments. Deep-Sea Res., 48(8), 1757-1792.

Zhang, Y., W. Maslowski and A.J. Semtner. 1999. Impact of mesoscale ocean currents on sea ice in high resolution Arctic ice and ocean simulations. 7. Geophys. Res., 104(C8), 18,409-18,429. 